\title{
Model Komunikasi Krisis Pelayanan Pasien di Rumah Sakit Umum Daerah
}

\author{
Jeanneth Priscilla ${ }^{1}$, Puji Lestari ${ }^{2}$ \\ ${ }^{1,2}$ Program Studi Ilmu Komunikasi, Fakultas Ilmu Sosial dan Ilmu Politik, \\ Universitas Pembangunan Nasional "Veteran" Yogyakarta \\ 1,2 Jalan Babarsari 2, Tambakbayan, Yogyakarta 55281, Indonesia \\ Email: jeannethpriscilla@gmail.com ${ }^{1}$; puji.lestari@upnyk.ac.id ${ }^{2 *}$ \\ *corresponding author
}

\begin{abstract}
The crisis arises due to inadequate handling of the organization in certain cases, such as in the Wonosari Regional General Hospital which is experiencing a service crisis. This study aims to find a crisis communication model of BPJS patient service at Wonosari Regional General Hospital in managing negative perceptions. The method used in this research is a descriptive qualitative approach, with crisis situation communication theory and apologia theory. Data collection techniques using interviews, observation, and literature study. The results of this study found a crisis communication model of BPJS patient services in the Wonosari Regional General Hospital. The substance of this study is a crisis communication model of BPJS patient care services in regional public hospitals that can be applied in other hospitals. Keywords: Crisis Communication Model, BPJS Patient Services, Wonosari Regional General Hospital
\end{abstract}

\begin{abstract}
Abstrak
Krisis muncul akibat kurang tepatnya penanganan organisasi dalam kasus-kasus tertentu, seperti di Rumah Sakit Umum Daerah Wonosari yang mengalami krisis pelayanan. Penelitian ini bertujuan untuk menemukan model komunikasi krisis pelayanan pasien BPJS Rumah Sakit Umum Daerah Wonosari dalam mengelola persepsi negatif. Metode yang digunakan dalam penelitian ini adalah deskriptif dengan pendekatan kualitatif, dengan teori komunikasi situasi krisis dan teori apologia. Teknik pengumpulan data menggunakan wawancara, observasi dan studi pustaka. Hasil penelitian ini menemukan model komunikasi krisis pelayanan pasien BPJS Rumah Sakit Umum Daerah Wonosari. Substansi penelitian ini berupa model komunikasi krisis pelayanan pasien BPJS kesehatan di rumah sakit umum daerah yang dapat diterapkan di rumah sakit lain.

Kata kunci: Model Komunikasi Krisis, Pelayanan Pasien BPJS, Rumah Sakit Umum Daerah Wonosari
\end{abstract}

\section{Pendahuluan}

Seluruh organisasi bisnis maupun non bisnis tidak pernah menginginkan terjadinya krisis (Koswara, 2014; Purwaningwulan, 2013) namun pada kenyataan krisis terjadi diseluruh organisasi dalam bidang apapun. Organisasi atau lembaga yang tidak dapat mengatasi krisis secara tepat dan efektif dapat menimbulkan beberapa akibat yang mampu menurunkan kredibilitas maupun reputasi lembaga atau organisasi.

Salah satu lembaga yang mengalami krisis adalah Rumah Sakit Umum Daerah Wonosari (RSUD Wonosari). RSUD Wonosari sebagai satu-satunya rumah sakit pemerintah dan terbesar di Wonsosari dan sudah berdiri sejak lama. RSUD Wonosari mengalami permasalahan pelayanan terhadap pasien yang menggunakan asuransi. Pasien yang menggunakan asuransi mengeluh karena pelayanan kurang baik dan tidak sesuai jargon RSUD, yaitu "Cepat, Bersih, Simpatik".

Hasil pra-penelitian dengan salah satu masyarakat asli daerah Wonosari mengatakan sudah sejak lama RSUD Wonosari terkenal dengan pelayanan yang kurang baik dan memberikan perlakuan yang berbeda antara pasien yang menggunakan asuransi dengan yang tidak menggunakan asuransi. Perawat bekerja lebih lamban, kurang ramah, kelalaian kerja dalam melayani pasien yang menggunakan asuransi, sehingga pasien lebih memilih untuk datang berobat ke praktikpraktik dokter di rumah dikarenakan sudah tidak percaya dengan RSUD Wonosari. 
Keluhan-keluhan yang dialami pasien secara perlahan menimbulkan persepsi negatif yang disusul dengan penurunan kepercayaan publik terhadap pelayanan di RSUD Wonosari. Pada akhirnya RSUD Wonosari mengalami krisis pelayanan akibat kurang tepatnya penanganan keluhan pasien. Penyebab kurang tepatnya penanganan tersebut antara lain sumber daya manusia yang kurang serta pengetahuan para tenaga medis untuk menanggapi serta mengatasi keluhan para pasien yang masih minim.

Menurut pengamatan peneliti melalui hasil wawancara prapenelitian, RSUD Wonosari hanya belum begitu maksimal melakukan komunikasi ditengah krisis untuk mengelola persepsi negatif mengenai kurang baiknya kualitas pelayanan pasien BPJS. Komunikasi menjadi sangat penting sebagai dasar asumsi, sehingga komunikasi krisis perlu segera diatasi agar tidak menimbulkan persepsi negatif (Juneza \& Purworini, 2016). Komunikasi Hal ini serupa dengan penelitian Hartiana (2014) mengenai persepsi perusahaan dalam berita krisis perusahaan. Hasil penelitian menunjukkan citra perusahaan semakin rusak akibat berita yang dikonstruksi negatif secara terus menerus sehingga dapat memberikan pengaruh negatif pula di dalam benak pembaca.

Penelitian lain mengenai krisis dilakukan oleh Yanuar (2017) menyatakan reputasi adalah senjatauntuk melawan krisis komunikasi. Instansi harus mengintegrasikan seluruh komponen dalam unsur komunikasi untuk membangun hubungan yang baik dengan stakeholders. Cara membangun hubungan yang strategis dengan menciptakan inovasi pengelolaan krisis pada organisasi, karena persepsi terhadap risiko dan kepercayaan konsumen saling mempengaruhi (Firdayanti, 2012). Penelitian ini fokus pada model komunikasi krisis RSUD Wonosari kepada pasien BPJS Kesehatan.

Krisis yang dialami oleh RSUD Wonosari dapat diatasi dengan melakukan komunikasi sehingga penelitian ini bertujuan untuk menemukan model komunikasi krisis pelayanan pasien BPJS Rumah Sakit Umum Daerah Wonosari dalam mengelola persepsi negatif. Teori Komunikasi Krisis Situasional (Situational Crisis Communication Theory)

Penelitian ini didasarkan pada Teori Komunikasi Krisis Situasional yang menunjukkan bahwa krisis masa lalu suatu organisasi menjadi ancaman, karena memengaruhi reputasi yang ditimbulkan oleh krisis tersebut Coombs, W. T. (2004). Reputasi adalah evaluasi yang dilakukan oleh para pemangku kepentingan tentang seberapa baik suatu organisasi memenuhi harapan para pemangku kepentingan berdasarkan perilaku masa lalunya. Reputasi diakui secara luas sebagai aset berharga dan tidak berwujud. Aset reputasi dapat menarik pelanggan, menghasilkan bunga investasi, meningkatkan kinerja keuangan, menarik karyawan berbakat, meningkatkan pengembalian aset, menciptakan keunggulan kompetitif, dan mengumpulkan komentar positif dari analis keuangan (Coombs, 2007). Reputasi RSUD Wonosari menjadi kurang baik, akibat adanya persepsi negatif yang timbul karena komunikasi krisis yang dialami RSUD Wonosari. Teori Apologia

Penelitian ini juga menggunakan teori apologia yang termasuk kedalam genre retorika teori apologia merujuk pada upaya pertahanan diri (self-defense) terhadap suatu tuduhan maupun serangan. Teori ini merupakan teori yang membahas mengenai strategi yang tepat dalam merespon krisis (Salma, 2017). Teori tersebut memiliki kesamaan prinsip dalam mengatasi krisis yaitu prioritas pertama untuk menjaga keselamatan stakeholder dengan mencegah stakeholder dari bahaya kerusakan atau kerugian fisik, ekonomi, sosial, budaya dan psikologi. Jika prioritas tersebut tercapai maka usaha merespon krisis bisa dilanjutkan dengan mengatasi berbagai isu yang 
berpotensi merusak reputasi, aset bernilai dari organisasi. Organisasi harus dapat merespon segala kritik, tuntutan, tuduhan dan anggapan yang tidak baik dari publiknya. Respon organisasilah yang menjadi fokus teori apologia karena berbagai kritikan dan tuntutan dapat menimbulkan krisis bagi keberlangsungan hidup sebuah organisasi.

Krisis dapat menimbulkan gangguan dan dampak besar (Sellnow \& Seeger, 2013), sehingga ketika krisis sedang terjadi dalam sebuah organisasi maka harus ada saling keterbukaan antara pihak manajemen dengan masyarakat. Hal ini dimaksudkan agar tidak muncul informasi-informasi yang tidak benar mengenai organisasi yang sedang dilanda krisis. Selain itu, keterbukaan informasi juga dapat mencegah timbulnya persepsi-persepsi yang negatif dari masyarakat terhadap sebuah organisasi. Strategi komunikasi dalam situasi krisis biasa disebut dengan komunikasi krisis, yang merupakan bagian dari strategi manajemen krisis. Kesalahan umum yang paling sering dilakukan oleh pimpinan organisasi yang tidak siap menghadapi krisis adalah bidang komunikasi.

Dalam melakukan komunikasi krisis, organisasi perlu melakukan pengelolaan. Beberapa hal harus dipertimbangkan dengan matang untuk melakukan proses komunikasi krisis. Hal-hal yang perlu dipertimbangkan dalam pengelolaan tersebut antara lain khalayak atau publik suatu organisasi, tujuan kegiatan komunikasi untuk masingmasing publik, pesan yang disampaikan, juru bicara, media komunikasi yang akan digunakan serta usaha untuk mendapatkan dukungan pihak ketiga. Hal pertama yang perlu dilakukan adalah pengenalan terhadap publik sasaran merupakan hal yang penting dalam program komunikasi krisis. Kemudian menentukan pesan atau informasi yang ingin disampaikan. Setelah itu menenetukan saluran komunikasi yang digunakan dalam menyampaikan pesan tersebut.
Selanjutnya adalah menentukan juru bicara yang menjadi perwakilan dari organisasi terkait dalam memberikan informasi.

\section{Metode Penelitian}

Penelitian ini menggunakan metode kualitatif dengan pendekatan deskriptif. Lokasi penelitian dilakukan di Rumah Sakit Umum Daerah Wonosari Jln. Taman Bakti No. 6, Wonosari, Kabupaten Gunung Kidul, Daerah Istimewa Yogyakarta 55851. Subyek penelitian ini adalah Humas RSUD Wonosari, Kepala bidang Pelayanan Medis RSUD Wonosari, pasien rawat inap BPJS Kesehatan RSUD Wonosari, dan beberapa masyarkat Wonosari. Obyek penelitian adalah komunikasi krisis yang dilakukan Rumah Sakit Umum Daerah Wonosari dalam mengelola persepsi negatif mengenai pelayanan kepada pasien yang menggunakan BPJS Kesehatan. Peneliti memilih RSUD Wonosari karena di Wonosari tidak banyak rumah sakit dan hanya ada satu rumah sakit pemerintah.

Teknik pengumpulan data dengan teknik: 1) observasi, peneliti melakukan observasi partisipasi pasif dimana peneliti berada di luar subyek dan tidak ikut dalam kegiatan-kegiatan yang ada di dalamnya, hanya berfokus pada aktivitas dari RSUD Wonosari yang berkenaan dengan permasalahan penelitian; 2) wawancara mendalam dengan Humas RSUD Wonosari, Kepala Bidang Pelayanan RSUD Wonosari, Pasien rawat inap BPJS Kesehatan serta beberapa masyarakat Wonosari; dan 3) studi pustaka dari jurnal yang relevan dengan penelitian ini. Teknik analisis data dalam penelitian kualitatif yang dilakukan pada saat pengumpulan data berlangsung dan setelah selesaipengumpulan data dalam periode tertentu. Data yang terkumpulkan berupa hasil wawancara dan observasi dipilih sesuai dengan kebutuhan penelitian dan ditampilkan dalam bentuk gambar, sehingga diperoleh kesimpulan berupa model komunikasi krisis pelayanan pasien BPJS di RSUD Wonosari. 


\section{Hasil Penelitian dan Pembahasan}

Hasil penelitian menunjukkan bahwa RSUD Wonosari memiliki tanda-tanda krisis yang dilihat dari: 1) keadaan fisik seperti bangunan terlihat tidak terurus, kebersihannya kurang baik alias kotor, kondisi mobil ambulans sudah cukup tua; 2) sumber daya manusia, yaitu para perawat, kebanyakan bekerja tidak sesuai prosedur yang tertulis, tidak ramah atau jutek bahkan ada yang marah-marah terhadap pasien, sehingga pasien merasa tidak nyaman dengan pelayanan di RSUD Wonosari; 3) produk andalan berupa jasa atau pelayanan kepada pasien juga tidak dapat diandalkan dibanding rumah sakit swasta yang ada di Wonosari sehingga pasien merasa tidak puas dengan pelayanan yang diberikan RSUD Wonosari; 4) sering muncul konflik antara RSUD dengan masyarakat dan pasien yang memprotes pelayanan yang tidak baik; 5) proses hukum, RSUD Wonosari pernah mendapat teguran dari Pemerintah Gunungkidul agar segera melakukan perbaikan layanan dikarenakan sering terjadi konflik dengan masyarakat. Hasil wawancara peneliti dengan beberapa pasien yang pernah mengalami kejadian buruk dengan RSUD Wonosari, menyatakan tidak berani mengadukan atau menuntut atas pengalaman yang dialami. Para pasien merasa takut dan tidak ingin membesar-besarkan permasalahan dan lebih baik ikhlas daripada mempermasalahkan. Konflik yang terjadi memang ditanggapi oleh pihak RSUD Wonosari, tetapi sebagian besar masyarakat tetap menilai rumah sakit ini tidak baik dalam memberikan layanan karena hal-hal tersebut memunculkan keresahan masyarakat.

Semua tanda krisis yang terjadi disadari oleh pihak rumah sakit. Hasil wawancara peneliti dengan beberapa narasumber di RSUD Wonosari menyatakan beberapa kasus bukan kesalahan dari pihak rumah sakit, melainkan kesalahpahaman antara SDM yang ada di lapangan dengan pasien, prosedur layanan dari BPJS Kesehatan kepada pasien BPJS yang dirujuk dari puskesmas. Hal inilah yang memunculkan persepsi RSUD
Wonosari membeda-bedakan antara pasien BPJS dan non-BPJS. Ada pula yang mengatakan pihak rumah sakit benar-benar menyadari krisis ini terjadi, karena pada saat itu SDM RSUD Wonosari masih sangat minim baik dari segi kuantitas dan kualitas. Akibatnya masyarakat menilai penanganan dari rumah sakit terkesan tidak ada dan kurang tepat. Hal-hal tersebut memunculkan krisis kepercayaan di RSUD Wonosari. Krisis yang dialami rumah sakit ini awalnya masuk dalam jenis operational crisis.

Sebelumnya telah dijelaskan alasan kasuskasus pelayanan di RSUD Wonosari semakin besar hingga menjadi krisis. Alasannya tidak lain adalah kurangnya penanganan yang tepat dari pihak RSUD Wonosari. Penjelasan sebelumnya pada saat itu SDM di rumah sakit ini masih terbilang kurang, baik dari segi jumlah dan pengetahuan, yaitu pengetahuan dalam menghadapi komplain dari pasien maupun dalam berkomunikasi dengan pasien ditambah dengan alasan lainnya. Akibatnya pihak dinilai RSUD Wonosari seperti tidak dapat menangani dengan benar operational crisis tersebut sehingga berubah menjadi potential crisis. Maka dari itu, RSUD Wonosari bekerja lebih keras dalam mengembalikan kepercayaan masyarakat ini. Pihak RSUD Wonosari harus mengatasi potential crisis yang dialami dengan perencanaan yang stratejik dan proses manajemen krisis.

Pihak RSUD Wonosari sudah berusaha melakukan perbaikan layanan dalam segi apapun, baik darikeadaan fisik, peningkatan SDM dari segi kuantitas dan kualitas, melakukan pendekatan kepada pasien dan masyarakat Wonosari melalui beberapa program yang dibentuk serta pengadaan layanan aduan, maklumat pelayanan dan survei kepuasan masyarakat agar terhindar dari konflik atau kesalahpahaman antara rumah sakit dengan pasien maupun masyarakat. Meski demikian, tetap masih ada masyarakat yang berpersepsi tidak baik terhadap rumah sakit yaitu masyarakat sudah tidak mau lagi datang berobat ke RSUD Wonosari dan tidak tahu mengenai 
perubahan yang telah dilakukan rumah sakit ini.

Risiko-risiko tidak dapat dihindari ketika krisis melanda suatu organisasi. Terkecuali organisasi tersebut melakukan penanganan yang cepat dan tepat, maka tidak semua risiko di atas dapat dialami. Semua risiko tersebut hanya dialami oleh sebuah organisasi yang cenderung mengabaikan tanda krisis dan tidak menangani dengan cepat serta tepat ketika krisis melanda. Risiko-risiko tersebut juga dialami oleh RSUD Wonosari. Risiko yang paling terlihat dari krisis kepercayaan ini adalah munculnya perspektif negatif ditengah masyarakat sehingga menurunkan kepercayaan dan nama baik rumah sakit. Hal ini terbukti dari wawancara peneliti dengan 12 masyarakat Wonosari yang pernah menjadi pasien di RSUD Wonosari. Para informan serentak menyatakan bahwa sudah menilai rumah sakit tersebut tidak baik dalam memberikan pelayanan.

Pernyataan dari 12 orang tersebut bukan tidak berdasar. Mereka pernah mengalami kejadian yang buruk berkaitan dengan pelayanan yang diberikan oleh RSUD Wonosari. Informan sudah trauma dan tidak ingin lagi datang berobat ke RSUD Wonosari, sehingga lebih memilih untuk datang ke rumah sakit swasta. Sebagian kecil dari informan menyatakan bahwa lebih baik membayar mahal untuk mendapatkan pelayanan yang sesuai dengan kebutuhan, dan yang lain menyatakan bahwa mereka datang berobat menggunakan BPJS ke rumah sakit swasta tetapi mereka juga mendapatkan pelayanan yang maksimal dibandingkan dengan pelayanan di RSUD Wonosari.

Alasan-alasan tersebut menunjukkan RSUD Wonosari mendapatkan perspektif negatif dari masyarakat sehingga menurunkan kepercayaan dan nama baik rumah sakit. Dari hal tersebut juga dapat dihubungkan dengan risiko yang lain yaitu memperlemah kemampuan organisasi dalam melakukan persaingan dengan kompetitor di pasar. Berdasarkan pernyataan dari 12 masyarakat tersebut juga dapat disimpulkan bahwa RSUD
Wonosari kalah saing dengan rumah sakit swasta yang notabenenya adalah rumah sakit dengan biaya cukup tinggi dibanding rumah sakit pemerintah. Secara tidak langsung, pernyataan dari 12 masyarakat tersebut juga menunjukkan lemahnya kemampuan RSUD Wonosari dalam memberikan pelayanan dibanding dengan rumah sakit swasta. Padahal keberadaan RSUD Wonosari sebagai fasilitas layanan kesehatan dari pemerintah dimaksudkan untuk mempermudah masyarakat mendapatkan layanan kesehatan dengan harga yang lebih terjamin bagi yang menggunakan BPJS maupun tidak.

Risiko lain yang dialami oleh RSUD Wonosari adalah terganggunya aktivitas normal di rumah sakit. Hal ini ditunjukan dengan adanya demo-demo atau aksi protes dari masyarakat yang sering kali terjadi di RSUD Wonosari. Karena aksi-aksi tersebut, aktivitas yang seharusnya berjalan baik di rumah sakit menjadi terganggu untuk mengurus pihak-pihak yang berdatangan. Pihak-pihak tersebut mewakili masyarakat yang seringkali mendapatkan pelayanan yang tidak baik dari rumah sakit. Maka dari itu, aksi demo tersebut dimaksudkan untuk meminta RSUD Wonosari melakukan pembenahan diri khususnya dalam hal pelayanan kepada pasien baik BPJS maupun non BPJS.

Adanya krisis juga menimbulkan risiko yaitu dapat merusak usaha-usaha organisasi untuk menciptakan pemahaman dan menaikkan hubungan mutual yang diharapkan dengan stakeholder. Risiko ini dialami oleh RSUD Wonosari. Banyak hal yang telah dilakukan RSUD Wonosari untuk mengubah perspektif dan mengembalikan kepercayaan masyarakat terhadap pelayanan. rumah sakit. Akan tetapi karena sering terjadinya kasus-kasus pelayanan yang memunculkan perspektif negatif dan kepercayaan masyarakat kepada rumah sakit turun mengakibatkan segala usaha yang dilakukan menjadi rumit. Rumah sakit harus bekerja lebih keras dibanding ketika tidak terjadi krisis. Dalam menjalankan 
usaha-usaha tersebut tentu rumah sakit perlu menyusun rencana strategis serta membutuhkan dukungan dan kerjasama dari beberapa pihak.

Risiko lain yang muncul di RSUD Wonosari yaitu keadaan yang tidak stabil atau kondisi yang memerlukan perubahan keputusan yang mendesak. Dari krisis tersebut, pihak RSUD Wonosari melakukan keputusan untuk merombak rumah sakit secara besar-besaran baik itu dari bangunanfisik, penambahankuantitasdankualitas sumber daya manusianya serta menuliskan standar-standar pelayanan yang wajib dilakukan bagi para SDM di RSUD Wonosari. Keputusan ini dilakukan secara mendesak mengingat sudah banyak sekali penilaian dari masyarakat dan aksi-aksi demo yang meminta rumah sakit untuk berbenah diri. Maka dari itu pemimpin tertinggi atau direktur rumah sakit memutuskan untuk melakukan perombakan secara besar-besaran.

Banyaknya kasus-kasus pelayanan yang tidak baik di RSUD Wonosari memunculkan persepsi negatif dari masyarakat sehingga menurunkan kepercayaan mereka kepada rumah sakit ini. Hal-hal tersebut telah dijelaskan sebelumnya dari adanya tanda dan risiko krisis yang dialami RSUD Wonosari. Oleh karenanya, pihak RSUD Wonosari bekerja lebih keras untuk mengembalikan nama baik maupun reputasi mereka. Tentunya dalam mengatasi sebuah kasus yang dapat memunculkan krisis tersebut diperlukan langkah-langkah atau proses pengelolaan yang tepat agar tidak menjadi semakin luas.

Langkah-langkah pengelolaan isu yang dapat memunculkan krisis setidaknya harus dimiliki oleh setiap organisasi dalam bidang apapun terlepas dari organisasi besar ataupun kecil. Tentunya dalam melakukan langkah-langkah tersebut diperlukan tim khusus manajemen krisis. Namun yang disayangkan RSUD Wonosari ini belum memiliki tim manajemen krisis yang khusus dibentuk untuk mengelola krisis. Pada saat krisis terjadi yang bertanggungjawab untuk mengelolanya masih sebatas pada pihak manajemen RSUD Wonosari saja yang terdiri dari direktur, kepala-kepala bidang, kepala seksi dan kepala subbag, ketua komite keperawatan dan ketua komite medis. Hal ini disampaikan oleh Ibu Mujiati selaku staf Humas RSUD Wonosari. Ada beberapa hal yang perlu diperhatikan dalam mengelola krisis (Prayudi, 2016:219): a. Adanya mekanisme untuk menentukan krisis potensial yang ada dalam perusahaan. Peran manajemen adalah meninjau kembalibidangbidang kegiatan yang mudah menimbulkan krisis. Dalam hal ini perlu dirancang suatu sistem peringatan dini berupa sistem pelaporan top-down dan bottom-up. Sistem di RSUD Wonosari sudah hampir seperti pada poin ini. Setiap bulan tim manajemen RSUD Wonosari mengadakan rapat untuk mengetahui hal-hal apa yang terjadi dalam sebulan berlalu pada setiap bidang di rumah sakit. Demikian juga kepala-kepala bidang setiap bulannya mengadakan rapat dengan anggotanya untuk membahas hal-hal yang terjadi pada sebulan berlalu dan apa saja yang harus ditingkatkan agar tidak terjadi isu-isu yang menmunculkan krisis baru.

b. Pengidentifikasian khalayak yang terpengaruh. Siapa saja yang terkena dampak langsung maupun tidak langsung oleh krisis. Dalam poin ini, pihak RSUD Wonosari ketika mengalami krisis yang menjadi fokus utamanya adalah stakeholder termasuk pasien yang terkait baru kepada masyarakat. Karena stakeholder di RSUD Wonosari merupakan khalayak yang dapat terkena langsung dampak dari krisis yang ada sedangkan masyarakat tidak terkena dampang secara langsung dari krisis yang ada.

c. Prosedur yang diikuti selama krisis. Biasanya berisi daftar yang harus dikerjakan, rangkaian langkah-langkah yang harus diikuti pembentukan pusat pengendalian krisis, tim manajemen krisis, dan prosedur komunikasi. Perlu diketahui bahwa RSUD Wonosari belum memiliki tim manajemen 
krisis. Jadi untuk saat ini, ketika ada isu atau krisis yang melanda rumah sakit yang menjadi pusat pengendalian dan prosedur komunikasi yang harus diikuti adalah dari direktur RSUD Wonosari.

d. Rencana kontingensi untuk melanjutkan aktivitas selama krisis. Berisi berbagai kemungkinan tentang fasilitas produksialternatif, pelayanan kepada pasar atau konsumen, atau kemungkinan menarik produk.

e. Pengangkatan dan pelatihan tim manajemen krisis. Pembentukan tim manajemen krisis menggunakan pertimbangan fungsional perusahaan, seperti public relations, hukum atau produksi. Rumah Sakit Umum Daerah Wonosari belum melakukan pengangkatan dan pelatihan tim manajemen krisis.

f. Rencana komunikasi krisis. Meliputi siapa saja yang akan ditunjuk menjadi juru bicara dan mengontrol informasi yang harus dikeluarkan agar tidak membingungkan khalayak sasaran, pemilihan media, dan penentuan pesan yang akan dikomunikasikan. Biasanya media adalah publik yang selalu ada dalam setiap manajemen krisis yang dilakukan oleh organisasi. Hal ini karena media bisa meningkatkan krisis tapi juga bisa meredakan krisis. Pada poin ini pihak RSUD Wonosari sudah melakukan rencana komunikasi krisis. Juru bicara dari RSUD Wonosari ketika adanya isu atau krisis adalah direktur atau kepala pejabat informasi daerah. Tentunya informasi yang disampaikan dari mereka tersebut sudah melalui rapat manajemen. Sedangkan untuk pemeilihan media, pihak RSUD Wonosari lebih menggunakan radio, televisi maupun koran karena sebagian besar masyarakat Wonosari masih menggunakan radio, televisi dan koran. Penentuan pesan juga direncanakan dalam rapat manajemen yaitu untuk menyampaikan pesan bahwa RSUD Wonosari tidak seperti dulu lagi, pelayanannya cepat, bersih dan simpatik g. Evaluasi terhadap krisis. Evaluasi dibutuhkan untuk mencermati apakah prosedur penanganan krisis sudah dilakukan dengan tepat dan bagaimana kasus serupa dimasa datang bisa ditangani lebih cepat. Untuk evaluasi terhadap krisis ini digabungkan dengan evaluasi yang dilakukan setiap bulan dalam rapat manajemen RSUD Wonosari. Jadi dalam rapat manajemen, semua hal berkaitan dengan isu atau krisis yang pernah dialami termasuk pemecahannya, perencanaan pelayanan kedepan maupun perbaikan dalam bidang tertentu dibahas dalam rangka meningkatkan nama baik maupun pelayanan di RSUD Wonosari. Langkah-langkah internal RSUD Wonosari sendiri dalam mengelola isu atau krisis dijelaskan oleh Mujiati selaku staf Humas RSUD Wonosari, yaitu sebagai berikut: a. Melakukan rapat manajemen dengan segera. Rapat manajemen dimaksudkan untuk melakukan identifikasi masalah yang muncul seperti mengetahui apa yang sebenarnya terjadi dan mengetahui opini-opini yang muncul melalui berita-berita yang ada. Jadi perlu dijelaskan, bahwa RSUD Wonosari hanya melakukan rapat manajemen ketika isu atau kasus yang terjadi ketika kasus tersebut tidak dapat diselesaikan oleh tim pengaduan. Dalam identifikasi masalah, pihak manajemen juga melakukan audit medis internal yaitu mencari tahu kronologi permasalahan, penyebab permasalahan terjadi, waktu dan tempat terjadinya masalah tersebut, pihak-pihak siapa saja yang dirugikan serta yang menjadi sasaran.

b. Setelah diketahui akar permasalahan dan opini-opini yang muncul maka pihak manajemen melakukan perencanaan terkait krisis yang dialami. Dalam hal ini adalah upaya apa saja yang harus dilakukan rumah sakit untuk mengatasi krisis agar tidak menjadi semakin luas. 
Dalam poin ini pihak RSUD Wonosari juga menentukan publik sasarannya, pesan yang ingin disampaikan kepada publik melalui media yang disepakati untuk digunakan sesuai dengan keadaan publiknya.

c. Rumah sakit melakukan tindakan komunikasi dengan pihak terkait. Apabila isu atau krisis tidak membutuhkan tanggung jawab yang tinggi karena pemicunya kesalahpahaman maka rumah sakit hanya memberikan edukasi khusus kepada pihak terkait melalui telefon atau face to face. Akan tetapi, jika pemicu permasalahan terjadi adalah kesalahan pihak rumah sakit dan membutuhkan tanggung jawab yang tinggi maka pihak rumah sakit mendatangi langsung rumah pihak yang terkait (face to face), memberikan bingkisan, melakukan pengembalian uang serta permohonan maaf. Disamping itu, pihak RSUD Wonosari juga mengirimkan press release kepada wartawan-wartawan yang berisi informasi atau penjelasan mengenai permasalahan yang terjadi serta upaya yang telah dilakukan rumah sakit. Dalam melakukan press relase atau press conference yang menjadi juru bicara adalah direktur atau kepala pejabat informasi daerah RSUD Wonosari. Tentunya press release dan press conference ini telah disepakati bersama isi informasi dan pesan yang ingin disampaikan kepada masyarakat agar tidak takut untuk datang berobat ke RSUD Wonosari. Pihak RSUD Wonosari sudah berbenah diri baik dari segi bangunan fisik, para tenaga medis maupun non medis sampai kepada standarstandar pelayanan yang ada. Sedangkan kepada pemerintah selaku pemegang saham dan organisasi yang terkait dengan rumah sakit ini, RSUD Wonosari memberikan laporan mengenai masalah yang terkait dan hal-hal apa saja yang telah dilakukan untuk mengatasi krisis tersebut. d. Pihak manajemen RSUD Wonosari kembali melakukan rapat untuk membahas peristiwa yang menimpa rumah sakit dan mendiskusikan kinerja rumah sakit kedepan agar tidak terjadi kesalahan-kesalahan yang sama serta membentuk program-program dalam rangka mengubah persepsi negatif yang masih tersisa dalam pikiran masyarakat. Program-program tersebut dibuat untuk memberikan pesan secara tidak langsung kepada masyarakat bahwa RSUD Wonosari sudah tidak seperti dulu lagi sertamemulihkan citra rumah sakit. RSUD Wonosari adalah rumah sakit yang cepat, bersih dan simpatik. Program-program yang dibentuk oleh RSUD Wonosari cukup banyak setelah melalui masa krisis kepercayaan tersebut. Hal ini bertujuan untuk membangun kembali hubungan yang sempat rusak dengan pasien maupun masyarakat serta mengembalikan citra rumah sakit. Program-program tersebut antara lain memantapkan layanan aduan, mengadakan survei kepuasan masyarakat setiap enam bulan sekali, mengadakan maklumat pelayanan sebagai bentuk komitmen RSUD Wonosari dalam memberikan pelayanan yang berkualitas, edukasi pasien di bangsal, temu pelanggan dengan keluarga pasien, pembagian leaflet, senam sehat untuk lansia setiap hari Jumat, pemeriksaan gratis setiap hari Minggu setelah senam bersama di Alunalun Gunugkidul, donor darah yang dilakukan setiap tahun, talk show di radio dan televisi, serta kegiatan-kegiatan lain di hari besar nasional.

Berdasarkan temuan peneliti di lapangan maka peneliti mendefinisikan sendiri komunikasi krisis yaitu segala bentuk komunikasi dalam bentuk program maupun secara langsung (face to face) yang dilakukan baik pada saat krisis sedang melanda sebuah organisasi sampai pada pasca krisis untuk mengembalikan nama baik organisasi. Alasannya adalah komunikasi itu tidak hanya sebatas serangkaian tahapan saja akan tetapi sampai pada pelaksanaannya juga masuk dalam komunikasi krisis, selama 
tujuannya adalah untuk mengembalikan nama baik atau mengelola persepsi negatif yang ada di masyarakat. Untuk itu komunikasi krisis bagi organisasi yang tengah mengalami krisis atau pasca krisis sangat penting untuk terus melakukan komunikasi agar tidak ada kesalahpahaman atau informasi yang simpang siur. Pengurangan risiko akibat kejadian yang terjadi di Wonosari harus diselesaikan dengan konsep desain yang jelas (Akhirianto, 2017), peneliti menemukan desain model komunikasi krisis (Gambar 1).

Gambar 1 merupakan model komunikasi krisis pelayanan pasien BPJS Kesehatan RSUD Wonosari. Model tersebut seirama dengan teori komunikasi situasi krisis juga menunjukkan bagaimana pentingnya untuk mengatur strategi pesan, agar dapat mempengaruhi frame media dan publik serta memilih media yang tepat sehingga masyarakat cenderung memiliki pandangan yang positif terhadap organisasi. Sampai sejauh ini media untuk menghindari krisis (Partao, 2005) yang digunakan oleh pihak RSUD Wonosari untuk menyampaikan informasi hanya radio dan televisi. Hal ini dikarenakan masyarakat Wonosari masih banyak yang menggunakan radio dan televisi dibanding media lain. Informasi yang disampaikan melalui radio dan televisi berupa penyampaian informasi kesehatan atau pelayanan di RSUD Wonosari. Jadi untuk strategi pesan, pihak RSUD Wonosari tetap berdasar pada motto rumah sakit yaitu cepat, bersih dan simpatik.

Program-program komunikasi maupun pelayanan di RSUD Wonosari sampai sejauh ini sudah dinilai cukup baik oleh pasien baik BPJS maupun non-BPJS serta masyarakat. Pernyataan tersebut juga dibenarkan oleh pasienpasien BPJS yang diwawancarai oleh peneliti.

Pasien-pasien di RSUD Wonosari sudah merasa puas dengan pelayanan di RSUD Wonosari. Beberapa dari mereka mengatakan bahwa pelayanannya sudah sangat jauh berbeda dengan dulu. Semua perawat sudah baik, ramah dan cepat tanggap dalam melayani pasien ketika dibutuhkan. Tidak ada lagi perbedaan antara pasien BPJS maupun bukan BPJS serta untuk mengurusnyajugasudah tidak terlalu susah seperti dulu. Kebanyakan alasan mereka kembali datang

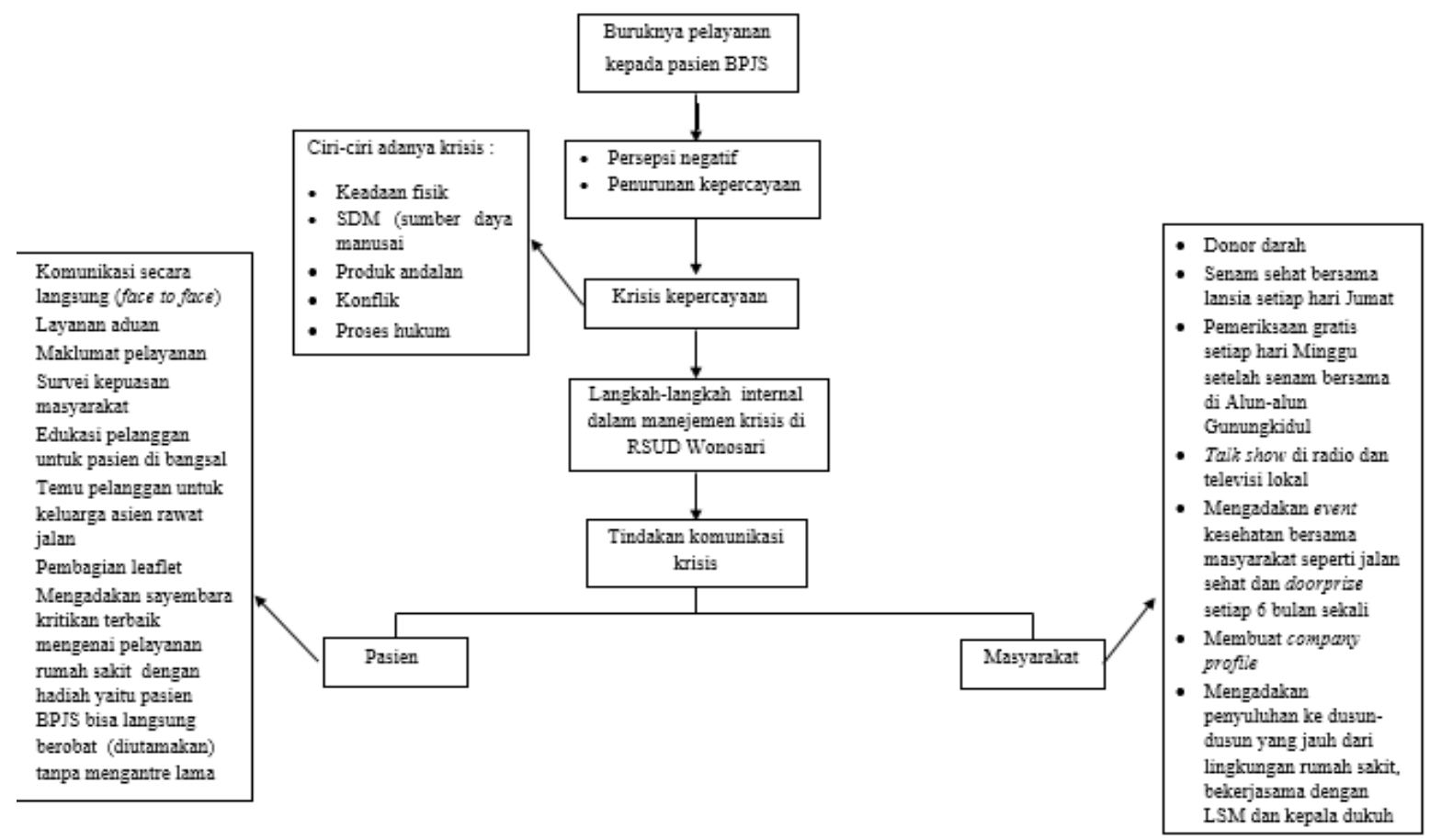

Gambar 1 Model Komunikasi Krisis Pelayanan Pasien BPJS Kesehatan RSUD Wonosari Sumber: Olahan Peneliti, (2019) 
ke RSUD Wonosari karena dekat dari rumah dan dirujuk dari puskemas sehingga mereka tetap ikut saja dengan surat rujukan. Mereka juga memiliki harapan yang sama untuk RSUD Wonosari kedepan yaitu lebih lagi meningkatkan kualitas pelayanan sesuai dengan kebutuhan pasien.

Sedikit berbeda dengan tanggapan beberapa masyarakat Wonosari yang diwawancarai oleh peneliti. Dari 15 orang yang diwawancarai hanya tiga orang yang berpendapat memang benar Rumah Sakit Umum Daerah Wonosari sudah berbenah diri dan berbeda dengan dulu, terlebih mengenai kualitas pelayanan. Sisanya yaitu 12 orang berpendapat mereka sudah tidak ingin lagi datang ke RSUD Wonosari walau sudah berbenah diri atau melakukan perbaikan. Mereka masih trauma dengan pengalaman sebelumnya. Hal ini terkait dengan teori Apologia membahas tentang usaha individu untuk mempertahankan diri atas serangan atau tuduhan telah melakukan kesalahan, termasuk serangan, yang melecehkan dirinya. Seiring berjalannya waktu teori Apologia menjadi suatu strategi bagi organisasi untuk menghadapi situasi krisis, yaitu komunikasi krisis atau merespon krisis. Teori ini memiliki kesamaan prinsip dengan teori komunikasi situasi krisis yaitu yang menjadi prioritas pertama adalah menjaga keselamatan stakeholder dengan mencegah stakeholder dari bahaya kerugian fisik, ekonomi, sosial, budaya dan psikologi. Respon organisasi dalam bentuk komunikasi dalam menghadapi krisis disebut organization apologia. Respon inilah yang menjadi fokus dari teori ini. Respon dalam teori ini berkaitan dengan tindakan komunikasi dan isi pesan yang akan disampaikan pada saat menghadapi situasi krisis.

Respon atau strategi apologia yang dilakukan oleh RSUD Wonosari adalah strategi konsiliasi (conciliation) (Wilandari, 2017). Strategi ini pada dasarnya adalah kerja sama dengan pihak lain yang bersebrangan namun berkesinambungan baik (Wibowo, Arifin, \& Sunarti, 2015). Organisasi menyatakan segala tuduhan dapat diterima dan menyampaikan permohonan maaf yang diikuti tindakan pembenaran atau perbaikan kerusakan dan berjanji tidak akan terulang kembali. Dalam strategi ini juga biasanya diikuti dengan pemberian komepensasi pada pihak yang dirugikan. Jika dikaitkan dengan permasalahan yang dialami RSUD Wonosari, sebagian besar kasus-kasus mengenai pelayanan kepada pasien BPJS disebabkan oleh rumah sakit sendiri.

Pihak Rumah Sakit Umum Daerah Wonosari menerapkan strategi konsiliasi ini. Mereka tidak melakukan penyangkalan atau mengelak ketika ada tuduhan dari publiknya mengenai kasus yang terjadi akibat perbuatan mereka. Pihak RSUD Wonosari dengan tulus menyampaikan permohonan maaf dengan mendatangi rumah pihak yang terkait dan bertemu secara tatap muka untuk diselesaikan secara kekeluargaan (face to face). Selain itu, pihak rumah sakit juga memberikan kenang-kenangan atau kompensasi tergantung dari kasus yang terjadi. Tidak hanya itu, pihak RSUD Wonosari juga melakukan pembenaran dalam hal ini melakukan perbaikan kualitas pelayanan dalam meningkatkan nama baik rumah sakit dan kembali menjadi rumah sakit yang dapat diandalkan oleh masyarakat Wonosari.Peningkatankualitas pelayanan dengan memperbaikicitrarumah sakitmemilikihubungan satu dengan yang lain (Rahayu \& Saryanti, 2014).

Rumah Sakit Umum Daerah Wonosari sudah berusaha memperbaiki reputasi ditengah krisis kepercayaan melalui komunikasi dan kegiatan-kegiatan yang rutin dilakukan. Semua hal itu dilakukan agar persepsi negatif masyarakat perlahan-perlahan dapat berubah. Meski sedang berusaha untuk dilakukan, tetap saja tidak semua masyarakat sudah menilai baik usaha-usaha yang dilakukan RSUD Wonosari. Masih cukup banyak masyarakat yang menilai RSUD Wonosari tidak baik dalam memberikan pelayanan, terlebih masyarakat yang tinggal dilingkungan sekitar RSUD Wonosari.

Menanggapi hal tersebut pihak RSUD Wonosari tidak bisa memaksakan keinginan masyakarat Wonosari untuk datang berobat 
ke RSUD Wonosari. Pihak RSUD tidak ingin memaksakan masyarakat, tetapi mereka terus berusaha untuk menjadi rumah sakit yang menyediakan pelayanan sesuai dengan kebutuhan pasien baik BPJS maupun non-BPJS. Penerimaan akreditasi paripurna pada tahun 2016 lalu serta program-program yang dibentuk bisa menjadi bukti bahwa rumah sakit ini tidak sama seperti dulu. Para pasien yang sudah datang dan merasakan perubahan baik di rumah sakit ini yang nanti akan bercerita diluar sana tentang perubahan rumah sakit ini. Diharapkan hal tersebutdapatmenggeserkembali persepsinegatif menjadi positif di benak masyarakat Wonosari.

\section{Simpulan}

Komunikasi krisis yang dilakukan dalam mengelola persepsi negatif yang muncul akibat buruknya pelayanan RSUD Wonosari kepada pasien BPJS antara lain komunikasi langsung atau face-to-face dengan cara menghubungi serta mendatangi langsung pihak terkait (korban). Kemudian pihak RSUD Wonosari memberikan kompensasi atau kenang-kenangan tergantung dari kasus yang terjadi. Tidak hanya itu, pihak RSUD Wonosari juga menyatakan permohonan maaf kepada pihak korban. Tentunya sebelum melakukan komunikasi krisis, pihak manajemen melakukan tahapan-tahapan manajemen komunikasi krisis antara lain identifikasi masalah, audit medis internal, perencanaan komunikasi krisis, pelaksanaan komunikasi krisis, evaluasi dan pemulihan nama baik. Respon pihak RSUD Wonosari ini termasuk dalam jenis respon concession dimana pihak rumah sakit menerima dan mau bertanggung jawab atas keasalahan yang dilakukan serta menyatakan permohonan maaf. Respon concession ini merupakan bagian dari teori komunikasi situasi krisis dimana pada teori ini, organisasi lebih mengutamakan korban dibanding sibuk mencari cara untuk mengembalikan reputasi.

Respon lain yang juga dilakukan oleh RSUD Wonosari adalah respon atau strategi konsiliasi.
Strategi ini merupakan bagian dari teori apologia yang memiliki kesamaan arti dengan respon concession yang berkesinambungan baik, namun strategi ini ditambahkan dengan bentuk perbaikan atau korektif dari organisasi. Berkaitan dengan strategi ini selain pihak RSUD Wonosari memberikan pertanggungjawaban, mereka juga melakukan tindakan perbaikan yaitu memperbaiki kualitas pelayanan serta kebijakankebijakan mengenai SOP yang ada di rumah sakit ini. Perbaikan-perbaikan tersebut juga dibarengi dengan munculnya program-program baru sebagai bentuk komunikasi yang berisi pesan bahwa RSUD Wonosari sudah berbenah diri dan tidak seperti dulu lagi. Dapat dikatakan RSUD Wonosari sudah mampu menggeser persepsi negatif masyarakat. Substansi penelitian ini berupa model komunikasi krisis pelayanan pasien BPJS kesehatan di rumah sakit umum daerah yang dapat diterapkan di rumah sakit lain.

\section{Daftar Pustaka}

Akhirianto, N. A. (2017). Community Based Landslide Disaster Risk Reduction a Design Concept. Jurnal Sains Dan Teknologi Mitigasi Bencana, 12(1), 32-43. Coombs, W. T. (2004). Impact of Past Crises on Current Crisis Communication: Insights From Situational Crisis Communication Theory. The

Journal of Business Communication (1973), 41(3), 265-289. https://doi. org/10.1177/0021943604265607 Coombs, W. Protecting Organization Reputations During a Crisis: The DevelopmentandApplication of Situational Crisis Communication Theory. Corp Reputation Rev 10, 163-176(2007). https:// doi.org/10.1057/palgrave.crr. 1550049 Firdayanti, R. (2012). Persepsi Risiko Melakukan E-commerce Dengan Kepercayaan Konsumen dalam Mmebeli Produk Fashion Online. Journal of Social and Industrial Psychology, 1(1), 1-7. 
Hartiana, T. I. P. (2014). Citra Perusahaan Dalam Berita Krisis Perusahaan. Jurnal Kajian Komunikasi, 2(2), 126-137. https://doi.org/10.24198/jkk.vol2n2.3 Juneza, R. R. D., \& Purworini, D. (2016). Respon Para Disabilitas terhadap Komunikasi Krisis BPBD (Badan Penanggulangan Bencana Daerah) dan Tim SAR Klaten Tahun 2016. Jurnal Profetik, 9(1), 80-96. https://doi. org/https://doi.org/10.14421/pjk.v9i1.1192

Koswara, A. (2014). KOMUNIKASI KRISIS: ANALISIS UPAYA RESPON KRISIS TELUK MEKSIKO DARI PERSPEKTIF PUBLIC RELATIONS. Edutect, 1(1), 107-131. https://doi.org/ doi.org/10.17509/edutech.v13i1.3224

Partao, Z. A. (2005). Optimalisasi Fungsi Media Relations untuk Keberhasilan Komunikasi Krisis. Jurnal Komunikologi, 2(1), 8-21. Purwaningwulan, M. M. (2013). Public relation dan manajemen krisis. Majalah Ilmiah UNIKOM, 11(2), 166-175.

Rahayu, B. S., \& Saryanti, E. (2014). Pengaruh Kualitas Pelayanan, Hubungan Pelanggan Dan Citra Perusahaan Terhadap Loyalitas Melalui Kepuasan Nasabah. Jurnal ADVANCE, 1(2), 11-25.

Salma, A. N. (2017). Berkomunikasi Saat Krisis: Strategi Penggunaan Media Internet dalam Menghadapi Krisis di Era Digital. In Prosiding Konferensi Nasional Komunikasi,
01, pp. 53-65. Retrieved from http://pknk. org/index.php/PKNK/article/view/47/52 Sellnow, T. L., \& Seeger, M. W. (2013). Theorizing Crisis Communication. (E. D. S. (University of C. S. B. James Aune (Texas A\&M University); Robert T. Craig (University of Colorado at Boulder); Leah Lievrouw (University of California Los Angeles); Alan Rubin (Kent State University, Ed.), The British Journal of Psychiatry (First, Vol. 111). West Sussex, PO19 8SQ, UK: WiletBlackwell: A John Wiley \& Sons, Ltd. https://doi.org/10.1192/bjp.111.479.1009-a Wibowo, D. H., Arifin, Z., \& Sunarti. (2015). Analisis Strategi Pemasaran Untuk Meningkatkan Daya Saing UMKM (Studi pada Batik Diajeng Solo). Jurnal Administrasi Bisnis, 29(1), 59-66. Retrieved from http:// administrasibisnis.studentjournal.ub.ac. id/index.php/jab/article/view/1172 Wilandari, R. (2017). Respon Krisis Keraton Kasunanan Surakarta Dalam Media. Komuniti: Jurnal Komunikasi Dan Teknologi Informasi, 8(1), 41-46. https:// doi.org/10.23917/komuniti.v8i1.2932 Yanuar, D. (2017). Kekuatan Integrated Communication untuk Membangun Reputasi dalam Menghadapi Krisis. Jurnal Komunikasi Global, 6(1), 1-14. 